\title{
Which Cultural Aspects do the Textbooks of Teaching Turkish to Foreigners Transfer?
}

\author{
Sami BASKIN \\ University of Gaziosmapasa, Taşlıçiftlik Kampüsü Tokat, Turkey
}

Corresponding Author: Sami BASKIN, E-mail: samibaskin@gmail.com

\section{ARTICLE INFO}

Article history

Received: December 28, 2017

Accepted: March 11, 2018

Published: April 30, 2018

Volume: 9 Issue: 2

Advance access: March 2018

Conflicts of interest: None

Funding: None

\section{Key words:}

Cultural Element,

Cultural Transfer,

Teaching Turkish as a foreign language, Textbooks

\begin{abstract}
Teaching a foreign language aims at not only teaching the language and language skills, but transferring the culture of the target language. The main reason for that is people learn the target language as a standby in addition to learning the language. It is important that the more individuals learn the cultural features of the country the more they understand the language better. It is an undeniable fact that language and culture are inseparable parts, so culture should be learned simultaneously while learning that language. Because of that relationship between language and culture, language teaching also means teaching culture. Foreign language textbooks reflect the characteristics of the language-speaking community and make it a cultural product of that language.
\end{abstract}

This study is to identify the place and importance of the textbooks used in teaching Turkish to foreigners in the target language teaching and to research which cultural items these books convey. Thus, A1-A2 level textbooks of the Turkish teaching set for Gazi Foreigners were selected as a sample and done document analysis to identify what these sources include in terms of "daily life, interpersonal relations, values and education, literature-arts and music, traditions and folklore, social life, geography and space, foreign (universal) cultural elements". It was observed that the elements of Turkish culture concentrated on the relation between daily life and interpersonal relations, and there was no balanced distribution among other cultural elements. Therefore, these books need to be reviewed so that they can raise cultural awareness of the students.

\section{INTRODUCTION}

Humanity has not lived alone up now; has lived as a society. He created culture as a member of a group called society. The most important role in transferring this culture to generations that have come after themselves is communication in the process of creating culture. Communication and culture are closely related issues in foreign language teaching. Especially nowadays, through the foreign language textbooks which are one of the most important means of transferring culture, communication skills are developed by creating intercultural awareness on students.

As the phenomenon of intercultural and multiculturalism began to take place in language teaching programs with the influence of European Common Language Criteria, the concept of culture has attracted attention especially in the field of foreign language teaching. One should know the culture of the language they are learning to meet the European Common Language Criteria. In addition, individuals are faced with a culture other than their own cultures and realize the other cultures around them. They can also develop different perspectives on their own cultures by recognizing and comparing these two cultures (İşci, 2012: 33).

Kongar (1999: 19) describes culture as the whole created by human beings in addition to the things that nature or god creates. According to this view, all kinds of tools, machinery, clothing, beliefs, values, attitudes are elements of a culture. According to Peck (1998) culture is the total amount of the accepted and regulated behavior of individuals. By this definition, culture can be regarded as a whole of social values separating a group of people from other people by connecting them together. Hyde and Kullman (2004: 59) also regarded culture as a complex structure composed by belief, art, morality, law and traditions as a whole in a society.

As it is understood from these definitions, it can be observed that all kinds of interactions between human beings, making and creating habits, 'spiritual' and 'material' works and products belong to the concept of culture (Soysekerci, 2015: 12). A foreign language always brings with it a foreign culture. It is very important to learn about the cultural characteristics of the country so that they can better understand the language.

It is an undeniable fact that language and culture are inseparable parts and that one should learn the culture while learning a language. According to Kramsch (1993), foreign language learners must also learn the target language culture. In his view, the language cannot be learned without learning the cultural context. Byram and Morgan (1994) also agree 


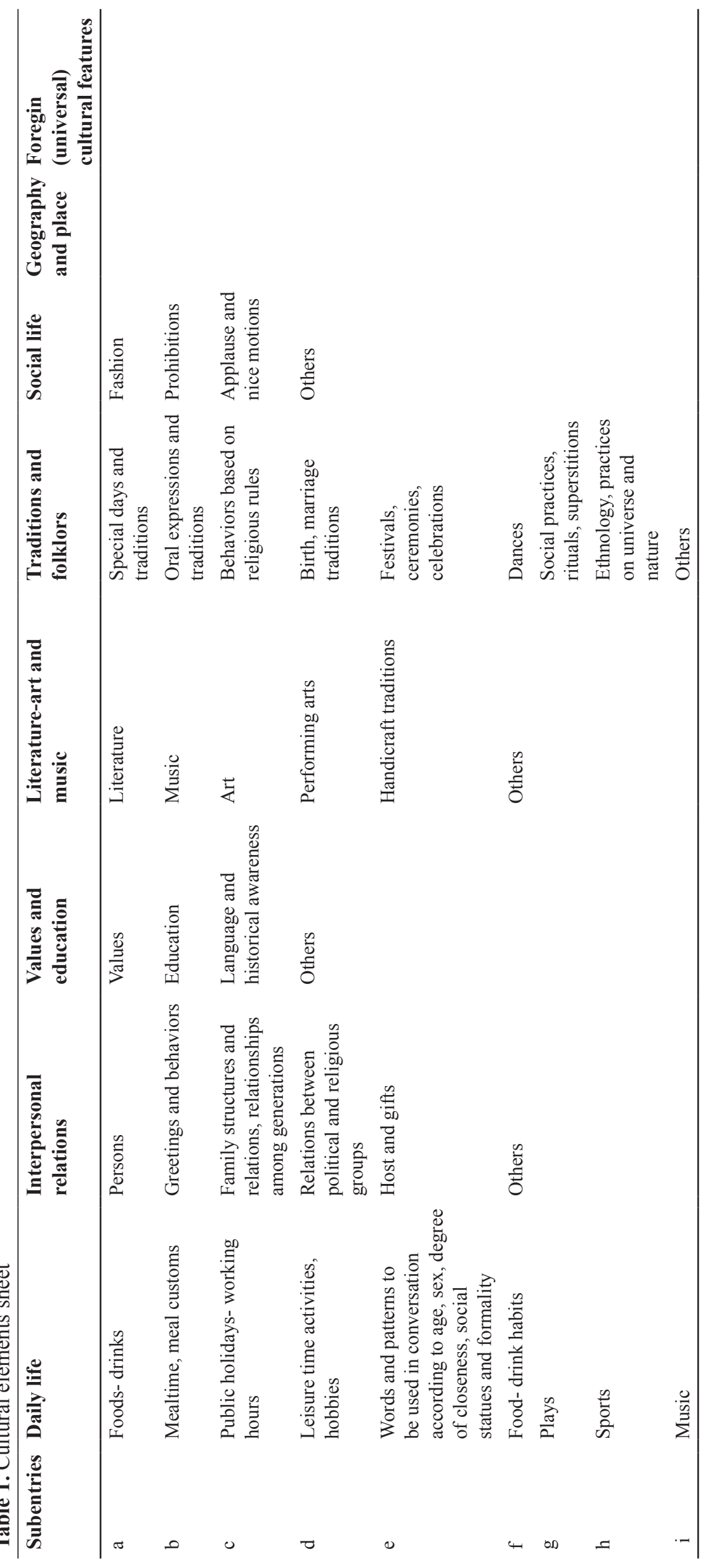


that cultural learning is an integral part of language learning. For this reason, it is necessary that students should be aware of the differences between their own cultures and the culture of the target language.

Teachers sometimes see the lectures related to the cultural subjects unnecessary in language programs. Engaging with them is nothing more than a waste of time for them. Instead, they opt for grammar vocabulary teaching in language teaching. Despite the fact that culture, language and literature together constitute three important elements of the language programs, culture is regarded as the weakest of these elements due to inconsistent practices in textbooks and lack of information about teachers' cultural teaching.

If the teacher thinks that culture is an integral part of language teaching, he has to deal with culture in language classes. It is the responsibility of teacher to investigate the ways of teaching and transferring culture and to make cultural learning easier for students. The teacher must find materials for cultural instruction or create materials for the students' use (İşcan, 2017: 31).

\section{The Use of Textbooks in Foreign Language Teaching and Cultural Transfer}

According to Hirschfelder (1982), teaching materials have a great influence on students' knowledge and their character development. Today, with many alternative teaching materials, textbooks continue to be an integral part of language learning in the classroom setting.

Textbooks that constitute the basis of foreign language teaching are also important elements of cultural transfer. Haley and Austin (2004) state that foreign language textbooks should, first of all, provide an appropriate language for the culture of the target language and provide activities purified from prejudices related to culture.

According to Cortazzi and Jin (1999), textbooks used in foreign language teaching can assume different tasks; they can be a teacher, a guide, a resource, an instructor, an authority.

The supervision of the quality of the textbooks used in teaching Turkish as a foreign language should not be ignored as the textbooks undertake this task in the field of teaching Turkish as a foreign language. Depending on the teacher's professional experiences and self-confidence, it is important to determine the success of the textbooks in accordance with the principles in which they are being held; to reach a better one and to increase the effectiveness of the course (Y1lmaz and Esen, 2016: 85).

In the textbooks which are one of the main tools of foreign language teaching, cultural concepts should be transferred in the context of life - experience fields besides teaching only grammar, and comparative and practical methods should be adopted in order to reach the mentioned aims. Among the textbooks based on source culture, target culture and international cultures, the most intentional ones are based on the target culture and international ones because they are reflecting the cultural diversity in the world while conveying the appropriate life styles in the target language culture (Özışık, 2004).

\section{Assessment Criteria of Cultural Elements in Textbooks Used in Foreign Language Teaching}

According to Kilıçkaya (2004), there are issues to be considered except for the needs of the students and the role of the teachers while examining the cultural content of textbooks. Each course book has its own distinctive program. This implicit program may involve socio-cultural factors, generalizations and stereotypes and may slow the development of intercultural communication. For this, it is necessary to take into consideration students' perspectives, perceptions and needs while transferring cultural items.

In this context, it is necessary to determine certain criteria while examining cultural elements in the textbooks.

In its declaration in 2000, the Council of Europe stated that the socio-cultural knowledge of foreign language should be dealt with in the programs. The socio-cultural information specified by the Council of Europe is:

1. Daily life,

- Food, drink, mealtime, meal customs.

- Public Holidays, Working hours.

- Leisure time activities, hobbies, reading habits, sports, etc.

2. Life conditions,

- Life standards,

- House conditions,

- Welfares,

3. Interpersonal communications,

- Class patterns and relations between classes,

- Man-woman relationships,

-Family patterns and relations, ties between generations

- Relations between political and religious groups,

4. Values, beliefs and behaviors,

- Social Class,

- Working communities,

-Welfare

- Revenue,

- Customs,

-Arts,

-Music etc.

5. Body Language,

6. Social Traditions,

-Alertness,

- Gifts,

- Dresses,

- Foods, Drinks,

- Prohibitions etc.

7. Traditional behaviors,

- Religious Situations,

- Birth, Marriage

- Marriage, shows, ceremonies, beatifications

-Festivals,

-Dances, etc. (as cited in Er, 2006: 8-9).

According to Brooks (1986), some of the cultural items that can be offered to students in foreign language teaching include:

-Greetings, saying goodbye, talks among friends.

- Introducing people.

-In conversation, words and patterns to be used according to age, sex, degree of closeness, social status, official style. 
-Questions that should not be asked.

-Traditions, games, music, telephone conversations.

- Writing a letter.

-Invite someone, make an appointment, hours.

- Eating and drinking habits,

- Traffic etc (Brooks, 1986, 124-128).

In the cultural awareness part of the UK National Program, it is emphasized that students should have knowledge about different countries and cultures, should compare target language cultures with their own cultures, and should have conversation with the target language speakers (Qualification and Curriculum, 1999).

Okur and Keskin (2013) examined cultural elements in Turkish textbooks as a foreign language under 7 main topics:

1. Daily life

2. Interpersonal relations

3. Values and training

4. Literature, art and music

5. Traditions and folklore

6. Social life

7. Geography and place

\section{METHOD}

This work is based on a qualitative research. The data were collected through a document review. A document review is an examination of any official or special written material that gives information about a subject that is being investigated (Creswell, 2012; Şimşek and Yıldırım, 2011). A researcher who wants to conduct qualitative research can collect data from general and private documents. Textbooks are frequently referenced sources for collecting data among general documents (Creswell, 2012). In this study A1-A2 level textbooks of the Turkish Instruction Set for Foreigners (Gazi University) are taken into consideration from the textbooks used in teaching Turkish with foreigners. All data classified and evaluated were obtained from these books. Findings were classified and evaluated under the titles of "daily life, interpersonal relations, values and education, literature-art and music, traditions and folklore, social life, geography and place, foreign (universal) cultural elements".

\section{Finiteness}

In Turkey there are many textbooks prepared for teaching Turkish to foreigners. İzmir, Yeni Hitit, Turkish for Foreigners (Gazi Kitabevi), Turkish for Foreigners (Gazi TÖMER), YETEM sets are the first ones that come to mind. A1-A2 books for Foreigners Turkish (Gazi TÖMER) set used as a course book in most of the teaching Turkish to foreigners centers of the universities like Gazi TÖMER was selected and examined as a sample. The study is limited to cultural elements only.

\section{Practice}

According to the Common European Framework of Reference for Languages, foreign language teaching books are prepared in accordance with the levels such as A1 and A2 for the initial level users, B1 and B2 for the intermediate users, and $\mathrm{C} 1$ and $\mathrm{C} 2$ for the advanced users. While foreign language teaching books are being prepared, cultural or linguistic elements as well as different or universal cultural elements are included. In the context of giving cultural objects, it is necessary to take into account from concrete to abstract principle and the level of the student.

In this study, as the focal point is the cultural elements of A1-A2 level, the other books are excluded from the scope. Eight main headings have been identified and classification has been made in accordance with these headings in order to present the cultural elements more clearly. These are the titles of "daily life, interpersonal relations, values and education, literature-art and music, traditions and folklore, social life, geography and space, foreign cultural elements". The data are presented in a table to determine which titles are more likely to be included. While this classification and tabulation is done, it has been utilized from the previous works done by Okur and Keskin (2013).

\section{Data}

\section{Below are some of the cultural elements found in textbooks}

\begin{tabular}{|c|c|c|}
\hline Subentries & $\begin{array}{l}\text { Transmission forms of } \\
\text { cultural elements }\end{array}$ & $\begin{array}{l}\text { Place } \\
\text { in book } \\
\text { level-page }\end{array}$ \\
\hline $1 \mathrm{a}$ & $\begin{array}{l}\text { Entrée: Patty } 7 \mathrm{tl} \text {, shepherd } \\
\text { roasting } 12 \mathrm{tl} \text {, mixed vegetable } \\
\text { with meat } 9 \mathrm{tl} \text {, meat stew } 10 \mathrm{tl} .\end{array}$ & A1-33 \\
\hline $1 b$ & $\begin{array}{l}\text { We congratulate after praying } \\
\text { and we have breakfast all } \\
\text { together. }\end{array}$ & A1-102 \\
\hline $1 d$ & $\begin{array}{l}\text { The ladies are chatting in the tea } \\
\text { garden. }\end{array}$ & A1-85 \\
\hline $1 \mathrm{e}$ & Son, I want to take my turn. & A1-67 \\
\hline $1 \mathrm{~h}$ & Wrestle & A1-102 \\
\hline $2 \mathrm{a}$ & $\mathrm{Hi}$, my name is Ahmet & A1-8 \\
\hline $2 b$ & Hello, bonjour. & A1-74 \\
\hline $2 \mathrm{c}$ & $\begin{array}{l}\text { I want to send some money to } \\
\text { my grandson's bank account. }\end{array}$ & A1-67 \\
\hline $2 \mathrm{e}$ & $\begin{array}{l}\text { Everyone serves various sweets } \\
\text { and pastries during the visits. }\end{array}$ & A1-102 \\
\hline $3 d$ & $\begin{array}{l}\text { I am an ambulance doctor. My } \\
\text { job is very tiring. unfortunately } \\
\text { it's not fun at all. sometimes a } \\
\text { traffic accident, sometimes a } \\
\text { suicide, sometimes a heart attack } \\
\text {. But when I rescue a person, } \\
\text { then I become the happiest } \\
\text { person in the world. }\end{array}$ & A2-6 \\
\hline $4 \mathrm{~b}$ & Tarkan & A $1-10$ \\
\hline $4 d$ & $\begin{array}{l}\text { I much heard about the play } \\
\text { named "Genç Osman" }\end{array}$ & A1-59 \\
\hline
\end{tabular}




\section{(Continued)}

\section{Below are some of the cultural elements found in textbooks}

\begin{tabular}{|c|c|c|}
\hline Subentries & $\begin{array}{l}\text { Transmission forms of } \\
\text { cultural elements }\end{array}$ & $\begin{array}{l}\text { Place } \\
\text { in book } \\
\text { level-page }\end{array}$ \\
\hline $5 \mathrm{a}$ & $\begin{array}{l}\text { We get up early in ramadan } \\
\text { festival. }\end{array}$ & A1-102 \\
\hline $5 c$ & $\begin{array}{l}\text { We congratulate after the and we } \\
\text { have breakfast all together. }\end{array}$ & A1-102 \\
\hline $6 b$ & $\begin{array}{l}\text { It is forbidden to park in the } \\
\text { street for a long period. }\end{array}$ & A1-53-52 \\
\hline 7 & $\begin{array}{l}\text { They were excited when they } \\
\text { saw chimney rocks. }\end{array}$ & A1-91 \\
\hline 8 & $\begin{array}{l}\text { I'm Jamila Anar. I'm 30. I'm } \\
\text { from Kazakhstan. }\end{array}$ & A1-13 \\
\hline $1 \mathrm{a}$ & $\begin{array}{l}\text { Adiyaman travel programme: try } \\
\text { dried grape and pomegranate. }\end{array}$ & A2-48 \\
\hline $1 d$ & ...I'm going to Archery club... & A2-67 \\
\hline $1 \mathrm{e}$ & Glad to be here./thank you & A2-14 \\
\hline 1f & $\begin{array}{l}\text { In the morning I have bagels, } \\
\text { pastries or biscuits. }\end{array}$ & A2-82 \\
\hline $2 \mathrm{a}$ & Emel chose a low cost menu. & A2-5 \\
\hline $2 \mathrm{e}$ & $\begin{array}{l}\text {... after meal, they offered us } \\
\text { turkish delight and sparkling } \\
\text { coffee. }\end{array}$ & A2-49 \\
\hline $2 \mathrm{f}$ & $\begin{array}{l}\text { I'm writing this letter to you in } \\
\text { england... warm regards. }\end{array}$ & A2-22 \\
\hline $4 a$ & $\begin{array}{l}\text { The sixth book of Ihsan oktay } \\
\text { anar, one of the masterpieces of } \\
\text { turkish literature, took place in } \\
\text { bookstores in september. The } \\
\text { author, with a wide imagination } \\
\text { in this book, will take the reader } \\
\text { to a new journey in different } \\
\text { worlds. }\end{array}$ & A2-8 \\
\hline $4 b$ & $\begin{array}{l}\text { Sezen Aksu, Işın Karaca, sertap } \\
\text { erener.... }\end{array}$ & A2-43 \\
\hline $4 c$ & $\begin{array}{l}\text { Famous turkish Poet Neşet Ertaş } \\
\text { was born in Kirşehir in } 1938 \text {. } \\
\text { UNESCO awarded him the } \\
\text { "living culture treasure" award } \\
\text { in } 2010 \text {. }\end{array}$ & A2-68 \\
\hline $4 \mathrm{e}$ & $\begin{array}{l}\text { Glass painting, miniature, } \\
\text { knitting, jewelry design. }\end{array}$ & A2-46 \\
\hline $5 d$ & $\begin{array}{l}\text {... I saw a village wedding. they } \\
\text { got sister zehra to take a horse, } \\
\text { and they shaved the groom in the } \\
\text { village square. }\end{array}$ & A2-69 \\
\hline $5 e$ & $\begin{array}{l}\text { All our staff and students are } \\
\text { invited to the "traditional spring } \\
\text { festival" of our university. }\end{array}$ & A2-11 \\
\hline $6 c$ & $\begin{array}{l}\text { Nuran goes to the national } \\
\text { library in ankara to prepare his } \\
\text { homework. she fills in the form } \\
\text { and joins the library in order to } \\
\text { get a book. }\end{array}$ & A2-72 \\
\hline
\end{tabular}

$($ Contd...)
(Continued)

Below are some of the cultural elements found in textbooks

\begin{tabular}{|c|c|c|}
\hline Subentries & $\begin{array}{l}\text { Transmission forms of } \\
\text { cultural elements }\end{array}$ & $\begin{array}{l}\text { Place } \\
\text { in book } \\
\text { level-page }\end{array}$ \\
\hline 7 & $\begin{array}{l}\text { Yedigöller national Park in bolu } \\
\text { is nearly a paradise corner . }\end{array}$ & A2-88 \\
\hline 8 & $\begin{array}{l}\text { Raw fish, rice, seafood and fresh } \\
\text { vegetables are indispensable to } \\
\text { Japanese cuisine. }\end{array}$ & A2-80 \\
\hline
\end{tabular}

\section{FINDINGS AND COMMENTS}

According to Table 2, the rate of cultural elements on daily life is $23,2 \%$ in Gazi A1 course book, $50 \%$ in Gazi A2 course book; the rate of cultural elements related to the interpersonal relations is $28.05 \%$ in Gazi A1 course book, $24.57 \%$ in Gazi A2 course book; The rate of cultural elements on values and education is $8.09 \%$ in Gazi A1 course book, 5.08\% in Gazi A2 course book; The rate of cultural elements on literature, art and music in Gazi A1 course book is 2,08\%, in Gazi A2 course book is 7,62\%; The rate of cultural elements related to traditions and folklore is $8.9 \%$ in Gazi A1 course book, $4.23 \%$ in Gazi A2 course book; the rate of cultural elements about social life is $4.4 \%$ in Gazi A1 textbook and $1.69 \%$ in Gazi A2 textbook; the rate of cultural elements related to geography and place is $14,9 \%$ in Gazi A1 course book, $12,71 \%$ in Gazi A2 course book; The rate about foreign cultural elements in Gazi A1 course book is 9,2\% and in Gazi A2 course book is 2,54\%. From this point of view, it can be seen that cultural elements related to daily life and interpersonal relations are given mainly in Gazi A1 and A2 textbooks. Since the course books are at the elementary level, it is natural that the elements of these two fields are given predominantly. However, it can be said that the lack of foreign cultural elements and the lack of a balanced distribution of local cultural elements are the shortcomings of the books.

\section{DISCUSSION AND CONCLUSION}

In the era we live in, the necessity of cultural transfer in foreign language education is an undeniable fact. The student should have the experience of familiarizing with his cultural values and values of target culture during the language learning process so that he can observe the differences between his own culture and target culture. In this case, cultural differences can be assessed unconditionally and without prejudice. In other words, with the awareness of common cultural values created by different functions in different societies, the student will improve his worldview and will not perceive values only as "true" or "false". Thus, the student will be able to see and recognize that the communities on earth have their own cultural systems and cultural objects in these cultural systems should be evaluated according to the cultural plan they are in.

Foreign language learning is actually a cultural process despite the fact that the main impetus is to learn the vocab- 
Table 2. Culture transmission rates of Gazi A1 ve Gazi A2 coursebook

\begin{tabular}{lcccccc}
\hline & \multicolumn{2}{c}{ GAZİ A1 } & & \multicolumn{2}{c}{ GAŻ $\mathbf{I} 2$} \\
\cline { 2 - 3 } \cline { 6 - 7 } & $\boldsymbol{f}$ & $\mathbf{\%}$ & & $\boldsymbol{f}$ & $\mathbf{\%}$ \\
\hline Daily life & 78 & 23,2 & & 59 & 50 \\
Interpersonal relationships & 94 & 28,05 & & 29 & 24,57 \\
Values and education & 30 & 8,9 & & 6 & 5,08 \\
Literature,aArt and music & 7 & 2,08 & & 9 & 7,62 \\
Traditions and andfFolklore & 30 & 8,9 & & 5 & 4,23 \\
Social Life & 15 & 4,4 & & 2 & 1,69 \\
Geography and place & 50 & 14,9 & & 15 & 12,71 \\
Foreign cultural elements & 31 & 9,2 & & 3 & 2,54 \\
Total & 327 & 100 & & 118 & 100 \\
\hline
\end{tabular}

ulary and syntax of the target language. Foreign language learning is an enculturation process. Throughout this process, the student will experience being more tolerant while learning the target language. $\mathrm{He}$ or she also will exhibit a universal approach to the events and phenomena he or she is observing or experiencing day by day. However, this is not an easy process. It usually happens simultaneously with language teaching. Each word and linguistic structure learned teaches you a piece of culture. Because of that cultural transfer in foreign language learning cannot be regarded as a process or a phenomenon that can take place spontaneously. All elements that are effective in language teaching (teacher, course book, setting, etc.) are quite influential in this cultural process. For example, teachers have an important role in transferring culture. Teachers have an important role in this process because they are involved in personal communication with students throughout the course of study and teaching. Students need their teacher's help in realizing their cultural values. With this creation of awareness, students can have the opportunity to compare their own cultures with the culture of the target language. In this way, culture transfer in foreign language teaching can be carried out effectively. This will enable students to improve their intercultural communication skills. Treating equally to the culture of target language together with one's own culture has a great importance and influence in the context of cultural exchange. Except for the mentioned statements, it is not expected that teachers will be able to achieve this by their own; instead, class materials should be arranged as suitable for culture transfer. Textbooks used in foreign language teaching should be meticulously and carefully selected according to certain criteria regarding the realization of cultural transfer. In foreign language teaching, the transfer of comparative culture has an important role. For example, in the textbooks only the target language culture should not be conveyed to students and the subjects that students can compare with their own culture should be considered. When the student is exposed to excessive cultural values of target language, the student will not be able to assimilate the subject as he cannot make a comparison, even if he understands the cultural structure of target language. This situation will affect the transfer of culture negatively. In this context, while textbooks and their context are selected, it is necessary to provide students with a comparison of the source culture and the universal cultural subjects, as well as the data on the target culture, in order to ensure that the cultural transfer can be properly performed. (Soysekerci, 2015).

When Gazi A1-A2 textbooks are analyzed in terms of culture transfer, it has been seen that Turkish culture, the target culture, contains many elements that are presented to the students in different ways and, in this way that the textbooks are sufficient enough to transfer Turkish culture to the students that are aimed to be taught Turkish. Although this is appropriate from the point of view of cultural transfer, when it is considered from the perspective of intercultural communication, it turns out that the student carries some shortcomings which will affect intercultural competence and cultural awareness.

Yilmaz (2012) researched culture transfer in the textbooks of the New Hittite series for Turkish for Foreigners, and in that study he found similar results. He stated that the books contain many different elements of Turkish culture that are presented to the students as the target culture and for this reason, the book can be regarded as successful in transferring Turkish culture to students. Okur and Keskin (2013), on the other hand, evaluated Istanbul Turkish Teaching Set for Foreigners in terms of cultural elements and found different results. They pointed out that cultural items were rarely used in the elementary level books, but they are used much in intermediate books. They think that it is necessary to benefit much more from the cultural elements. Lappalainen's (2011) results of his master thesis study in which he examines the transfer of American culture in foreign language course books are consistent with the results of this study. As a result of his work, he found that textbooks do not fully support intercultural learning and teaching principles, and that American culture is very limited when compared to other cultures. Karababa and Taşkın (2012) evaluated course books used in teaching Turkish as a foreign language in terms of teachers' opinions and emphasized the visuality and themes in the books as different from this study. In the result of the research, it is confirmed that New Hittite Turkish Course Books for Foreigners are sufficient in terms of visuality and that visuals provide unity with the texts; it has been found that the texts in the books provide unity with the unit themes.

As a result, while cultural texts are given in foreign language textbooks, it can be said that there should be a proportional balance between local cultural elements and universal cultural elements as intercultural transfer is very important in today's language teaching. Teachers have a great role in this respect. In this context, foreign language learners should be told that there is not only a single thought and life system in the world; there are also different cultural groups and living styles. What should be noted here is to ensure that students have the opportunity of comparing these different cultural groups and lifestyles with their own life and thoughts, in other words with their culture. Choudhury (2014) argues that students in foreign language classes should be taught English in connection with their own culture. Thus, students 
can show behaviors of correct cultural awareness. Authors who prepare foreign language textbooks should also agree on this point. To them, students should be able to find the opportunity of comparing different cultural values with the target culture in the books.

\section{REFERENCES}

Byram, M. \& Morgan, C. (1994). Teaching and learning -language and culture-. Clevedon: Multilingual Matters Ltd.

Brooks, N. (1986). Culture in the classroom. In culture bound. Bridging the cultural gap in language teaching (ed. J.M. Valdes), pp. 123-128. Cambridge: Cambridge University Press.

Choudhury, R. U. (2014). The role of culture in teaching and learning of English as a foreign language. Express, an international journal of multi-disciplinary research, 1(4), pp. 1-20.

Creswell, J. W. (2012). Educational research: planning, conducting, and evaluating quantitative and qualitative research. Boston: Pearson.

Cortazzi, M., \& Lixian, J. (1999). Cultural Mirrors'. In culture in second language teaching and learning (Ed. by. Eli Hinkel), Cambridge, Cambridge UniversityPress, pp. 196-219.

Er, K.O. (2006). The Effects of Culture in Foreign Language Curriculum, Ankara Üniversitesi Ĕgitim Bilimleri Dergisi, 39, pp. 1-14.

Haley, M. H. and Austin, T., Y. (2004). Content-based second language teaching and learning: an interactive approach. Cambridge: Pearson Publishing

Hirschfelder, A. (1982). American Indian stereotypes in the world of children: a reader and bibliography. New Jersey: The Scarecrow.

Holiday, A., Hyde, M. and Kullman, J. (2004). Intercultural communication, an advanced resource book. London: Routledge.

İşcan, A. (2017). Filmlerle yabancılara türkçe ögrretimi. Ankara: Nobel Akademik Yayıncılik.

İşci, C. (2012). Türkçenin yabancı dil olarak öğretiminde kullanılan "yeni hitit" ders kitabının dört temel dil becerisi ve kültür açısından incelenmesi. Yayımlanmamış yüksek lisans tezi. İzmir: Dokuz Eylül Üniversitesi Eğitim Bilimleri Enstitüsü.

Karababa, Z. C., and Üstünsoy-Taşkın, S. (2012). Yabancı dil olarak Türkçe öğretiminde kullanılan ders kitaplarının öğretmen görüşleri çerçevesinde değerlendirilmesi. Dil dergisi. 157, pp. 65-81.

Kılıçkaya, F. (2004). Guidelines to evaluate cultural content in textbooks. The internet TESL journal, 10(12), pp. 38-48.

Kongar, E. (1999). Kültür üzerine. İstanbul: Remzi Kitapevi Kramsch, C. (1993). Context and culture in language teaching. Oxford: Oxford University Press.

Lappalainen, T. (2011). Presentation of the American Culture in EFL textbooks: An analysis of the cultural content of Finnish EFL textbooks for secondary and upper secondary education. Unpublished Master's thesis. [online] https://jyx.jyu.fi/dspace/bitstream/handle/123456789/26866/URN: NBN:fi: jyu2011050310724.pdf?sequence=1. (25 March, 2017).

Okur, A., Keskin, F. (2013). Yabancılara Türkçe öğretiminde kültürel ögelerin aktarımı: İstanbul yabancılar için Türkçe öğretim seti örneği. International journal of social science, 6(2), pp. 1619-1640.

Peck, D. (1998). Teaching culture: beyond language. Yale: New Haven Teachers Institute.

Soyşekerci, G. (2015). İngilizce ve Türkçe ders kitaplarında kültürel öğelerin incelenmesi. Yayımlanmamış yüksek lisans tezi. İzmir: Dokuz Eylül Üniversitesi, Eğitim Bilimleri Enstitüsü.

Yıldırım, A., and Şimşek, H. (2011). Sosyal bilimlerde nitel araştırma yöntemleri. Ankara: Seçkin Yayıncılık.

Y1lmaz, F., (2012). Cultural transmission through teaching turkish as a foreign language course books. Turkish studies. 7(3), pp. 2751-2759.

Yılmaz, H., and Esen, D. (2016). Türkçenin Yabancı Dil Olarak Öğretiminde Kullanılan Ders Kitaplarını Değerlendirme Ölçütleri, In Yabancllara Türkçe Öğretimi Üzerine Araştırmalar (ed. by Alparslan Okur, Bekir İnce and İsmail Güleç). pp. 85-96. Sakarya: Sakarya Üniversitesi Tömer Yayınları. 